\title{
The Indonesian throughflow, its variability and centennial change
}

\author{
Ming Feng ${ }^{1,2^{*}} \mathbb{0}$, Ningning Zhang ${ }^{3}$, Qinyan Liu ${ }^{4}$ and Susan Wijffels ${ }^{1,2}$
}

\begin{abstract}
The Indonesian Throughflow (ITF) is an important component of the upper cell of the global overturning circulation that provides a low-latitude pathway for warm, fresh waters from the Pacific to enter the Indian Ocean. Variability and changes of the ITF have significant impacts on Indo-Pacific oceanography and global climate. In this paper, the observed features of the ITF and its interannual to decadal variability are reviewed, and processes that influence the centennial change of the ITF under the influence of the global warming are discussed. The ITF flows across a region that comprises the intersection of two ocean waveguides - those of the equatorial Pacific and equatorial Indian Ocean. The ITF geostrophic transport is stronger during La Niñas and weaker during El Niños due to the influences through the Pacific waveguide. The Indian Ocean wind variability associated with the Indian Ocean Dipole (IOD) in many years offsets the Pacific ENSO influences on the ITF geostrophic transport during the developing and mature phases of EI Niño and La Niña through the Indian Ocean waveguide, due to the co-varying IOD variability with ENSO. Decadal and multi-decadal changes of the geostrophic ITF transport have been revealed: there was a weakening change from the mid-1970s climate regime shift followed by a strengthening trend of about 1 Sv every 10 year during 1984-2013. These decadal changes are mostly due to the ITF responses to decadal variations of the trade winds in the Pacific. Thus, Godfrey's Island Rule, as well as other ITF proxies, appears to be able to quantify decadal variations of the ITF. Climate models project a weakening trend of the ITF under the global warming. Both climate models and downscaled ocean model show that this ITF weakening is not directly associated with the changes of the trade winds in the Pacific into the future, and the reduction of deep upwelling in the Pacific basin is mainly responsible for the ITF weakening. There is a need to amend the Island Rule to take into account the contributions from the overturning circulation which the current ITF proxies fail to capture. The implication of a weakened ITF on the Indo-Pacific Ocean circulation still needs to be assessed.
\end{abstract}

Keywords: Indonesian throughflow, ENSO, Indian Ocean dipole, Decadal variations, Climate change, Island rule, Overturning circulation

\section{Introduction}

The ITF provides a low-latitude pathway for warm, fresh waters from the Pacific to enter the Indian Ocean through the Indonesian seas (Gordon 2005). The ITF transport is an important regulator of the meridional overturning of the Indian and Pacific Oceans, and possibly the global thermohaline circulation (Gordon 1986; Sloyan and Rintoul 2001). Wyrtki (1961) produced

\footnotetext{
*Correspondence: ming.feng@csiro.au

${ }^{1}$ CSIRO Oceans and Atmosphere, Indian Ocean Marine Research Centre, Crawley, WA, Australia

Full list of author information is available at the end of the article
}

quantitative description of the seasonally varying flow patterns in the warm seas surrounding Indonesia, providing the first estimate of the strength of the Indonesian throughflow (ITF). Since then, there have been great efforts to estimate the ITF transport using observations (Godfrey and Golding 1981; Fieux et al. 1994, 1996; Meyers et al. 1995). The most comprehensive observations of all the major Indonesian channels were during the International Nusantara Stratification and Transport Program (INSTANT (Gordon et al. 2010; Sprintall et al. 2004, 2009), when simultaneous measurements were conducted in the major inflow and outflow passages from the end of 2003 to early 2007), and the ITF transport was 
estimated to be around $15 \mathrm{~Sv}\left(1 \mathrm{~Sv}=10^{6} \mathrm{~m}^{3} \mathrm{~s}^{-1}\right)$ during the 3-year period (Fig. 1).

Although the ITF is regarded as an important component of the Indo-Pacific and global overturning circulation, its transport and variability have been estimated using wind-driven circulation theory. There is still lack of general understanding on how the deep overturning circulation contributes to the ITF transport. In this study, we review the variability and dynamic drivers of the ITF in literatures, and emphasize on a potential connection between the overturning and wind-driven circulations in the contribution to the ITF. We introduce the roles of the ITF in ocean circulation and climate in the Indo-Pacific Ocean; and the sources of the ITF water (and their fate) in the Indian Ocean; after reviewing the interannual variations of the ITF volume transport, we then discuss the centennial trend of the ITF under the influence of the global warming.

\section{The role of the ITF on ocean circulation and climate}

As the only pathway that connects different ocean basins in the tropics (Sprintall et al. 2014), the ITF plays an important role in heat and water volume balances in the Indian and Pacific Oceans. In the Indian Ocean, the ITF water is advected westward in the South Equatorial Current, and then flows south along the African coast, contributing to the Agulhas Current (Godfrey and Golding 1981; Godfrey 1996). The ITF waters can spread southward along the western Australian coast as a source of the Leeuwin Current, under the forces of the meridional

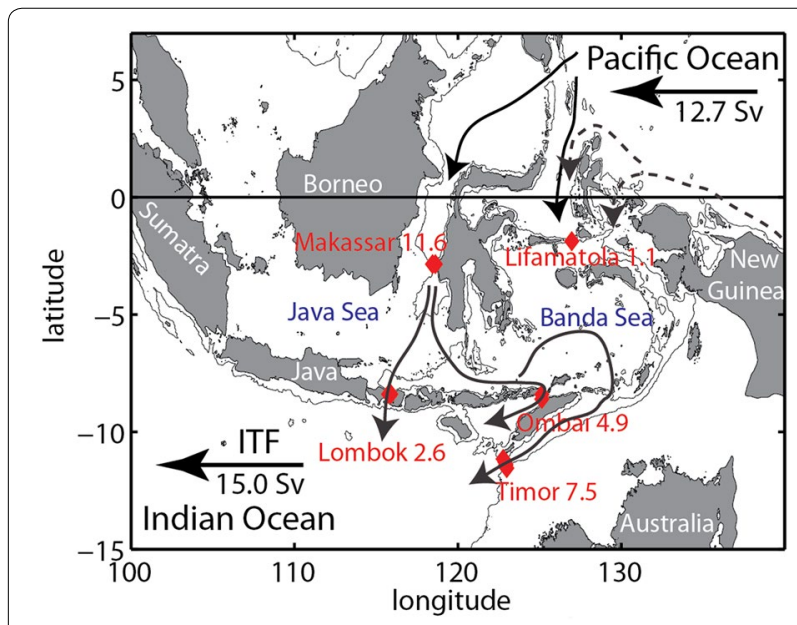

Fig. 1 Transport of the currents contributing to the Indonesian Throughflow via different passages. Transport of the currents contributing to the Indonesian Throughflow (ITF) via different passages through the Indonesian archipelago (after Wikipedia with transport values from Sprintall et al. 2009). Numbers next to current arrows indicate transport in Sverdrups (Sv) steric height gradient in the southeast Indian Ocean (Gentilli 1972).

Numerical models and observations have indicated that changes in ocean circulation associated with the ITF are likely to affect patterns of circulation, thermal structure and air-sea exchange in widely separated regions (Macdonald 1993; Godfrey 1996; Lee et al. 2002; Vranes et al. 2002). In the Indian Ocean, the ITF is shown to warm the Agulhas Current and the region off the south coast of Java and Sumatra, strength the Leeuwin Current system and increase the steric height throughout the Indian Ocean (Qu et al. 1994; Godfrey 1996). In south Pacific, the ITF tends to reduce the transport of East Australian Current and thus cool the Coral Sea and Tasman Sea (Godfrey and Golding 1981; Godfrey 1996). Furthermore, the cooling effect of the ITF in the Pacific can be seen in the eastern equatorial Pacific, induced by the upwelling Kelvin wave excited by the ITF (Godfrey 1996).

The ITF exports a large amount of heat and freshwater from the Pacific to the Indian Ocean, and cools the Pacific and warm the Indian Ocean (Hirst and Godfrey 1993; Godfrey 1996). Difference between model results with the ITF open and closed show that there are significant changes in heat flux in regions such as seas around eastern Australia (Tasman Sea), western Australia (Leeuwin Current), southern Indian Ocean (Agulhas Current), North Pacific and South Pacific (Hirst and Godfrey 1993). It is likely that most of the ITF heat transport derived from the Pacific Ocean is lost to the atmosphere in the southwest Indian Ocean (Godfrey 1996), consistent with assessment from observations (Vranes et al. 2002).

The ITF may affect El Nino- Southern Oscillation by modifying tropical-subtropical exchanges, mean tropical thermocline structure, mean Sea Surface Temperature (SST) difference between the warm pool and cold tongue (Lee et al. 2002), or by affecting the SST in the Indonesian seas and the development of westerly wind bursts (Nicholls 1984; Godfrey 1996). Transmission of the multidecadal signal occurs via an oceanic pathway through the Indonesian throughflow and is manifest across the Indian Ocean centered along $12^{\circ} \mathrm{S}$ as westward-propagating Rossby waves modulating thermocline and subsurface heat content variations. Low-frequency changes in the eastern Indian Ocean thermocline depth are associated with decadal variations in the frequency of Indian Ocean dipole (IOD) events, with positive IOD events unusually common in the 1960s and 1990s with a relatively shallow thermocline (Ummenhofer et al. 2017). SSTs in the central Indian Ocean linked previously to rainfall deficit in the western Australian winter may be dependent on the ENSO related variability of the ITF (Murtugudde et al. 1998). 


\section{Sources and pathways of the ITF water}

There has been a consensus that the ITF is a mixture of Pacific waters from both northern and southern hemisphere. On the basis of water mass analysis, Wyrtki (1961) suggests that the Mindanao Current continuously penetrates into the Celebes Sea, and then flows to the Indian Ocean via the Macassar Strait, then towards the south into the Flores, Banda and Timor Seas. Observations have confirmed that the ITF enters from the North Pacific via the Mindanao Current (Godfrey et al. 1993, 1996; Gordon and Fine 1996). Fine (1985) and Gordon (1986) gave direct evidences of source from North Pacific by examining the tritium and temperature-salinity distribution, respectively. And in their views, the waters from the South Pacific are too low in tritium and high in salinity to be a major source (Fine 1985; Gordon 1986). The water within the thermocline of the Indonesian seas is derived for the most part from the North Pacific, through the Mindanao Current and then Makassar Strait; whereas the source water for lower thermocline is drawn from the South Pacific via the Halmahera Sea (Gordon and Fine 1996; Gordon 2005).

Deep water masses from the Southern Ocean crisscross the tropical Pacific within the upwelling regimes of the zonal equatorial currents to enter the North Pacific before ultimate export to the Indian Ocean as the ITF (Gordon and Fine 1996). Waters from the South Pacific can reach the Mindanao Current through nonlinear retroflection processes (Godfrey et al. 1993, 1996). Observations of salinity, temperature and chemical-tracer data report that besides the North Pacific water, the throughflow has a second pathway as water through an eastern route of Maluku to Seram to the Banda Sea, mainly as a deep throughflow (Gordon and Fine 1996; van Aken et al. 2009). And the deeper ITF is dominated by saline South Pacific lower-thermocline water penetrating into the Seram Sea, with a seasonal cycle in the ratio of the North and South Pacific sources (Gordon and Fine 1996). It is illustrated that the structure of the opposing and retroflecting currents situated to the east of the Indonesian passages determines the origin and composition of the ITF. Furthermore, nonlinear effects resulting from the retroflection of the South Equatorial Current cause most of the throughflow to originate from the north as observed by using a simplified channel model (Nof 1996).

The ITF waters experience intensive mixing in the Indonesian Seas due to tidal mixing and air-sea exchanges before exit into the Indonesia-Australian Basin of the Indian Ocean (Ffield and Gordon 1996; Koch-Larrouy et al. 2015). The ITF transport joins the South Equatorial Current in the southeast Indian Ocean. After water mass modifications in the interior Indian Ocean, most of the ITF waters eventually feed into the Agulhas Current and then partly being leaked into the Atlantic through the Agulhas Leakage (Durgadoo et al. 2017). The Agulhas leakage transport may have important roles in modulating the strength of the Atlantic overturning circulation. Some of the ITF water recirculates in the Eastern Gyral Current before feeding the Leeuwin Current (Domingues et al. 2007; Menezes et al. 2013; Van Sebille et al. 2014). The ITF transport is important for basin-scale heat and freshwater budget in both the Pacific and Indian Ocean (Vranes et al. 2002).

The South China Sea (SCS) is the largest marginal sea in the southeastern Asian waters. It connects in the south with the Sulu and Java Seas through the Mindoro $(>200 \mathrm{~m})$ and shallow Karimata $(<50 \mathrm{~m})$ straits. The SCS is a semi-closed basin below about $200 \mathrm{~m}$. On the longterm average this heat and freshwater gain can only be balanced by horizontal advection, with inflow of cold and salty water through the Luzon strait and outflow of warm and fresh water through the Mindoro and Karimata straits. This circulation has been termed as the South China Sea throughflow (SCSTF) (Qu et al. 2006; Wang et al. 2006). The South China-Indonesian Seas Transport/Exchange (SITE) program in 2007-2016 measured the SCSTF in the Karimata and Sunda Strait (Fang et al. 2010; Susanto et al. 2013).

\section{The ITF transport and its Interannual and decadal variations}

Wyrtki (1961) provided the first estimate of the transport of the ITF based on hydrographic observations, sea level records, ship drifts, and climatological wind pattern, of $1.7 \mathrm{~Sv}$ in the top $200 \mathrm{~m}$. Since then, there have been exceptional efforts in determine the ITF transport from both direct in situ observations and inverse models based on basin scale hydrography surveys, with the ITF transport derived from the inverse models being sensitive to the model assumptions. Godfrey and Golding (1981) used hydrographic data along an unclosed section in the southeast Indian Ocean to derive the geostrophic transport of the ITF to be around 10Sv. Based on a hydrographic section designed to measure the entire ITF, the total ITF transport was estimated to be $18.7 \mathrm{~Sv}$ in August 1989 (Fieux et al. 1994), and - 2.6 Sv in February 1992 (Fieux et al. 1996). Based on XBT observations between Australian and Indonesian along the IX1 section, Meyers (1996) reconciled these extreme observations as part of annual and interannual variations of the ITF. From the XBT observations, the upper $400 \mathrm{~m}$ geostrophic transport of the ITF was 5Sv (Meyers et al. 1995). A deeper reference depth at $750 \mathrm{~m}$ for the XBT observations give a similar result (Wijffels et al. 2008). A best estimate of the 20-year-average geostrophic plus Ekman transport along 
the IX1 section is $8.9 \pm 1.7 \mathrm{~Sv}$ with a transport-weighted temperature of $21.2^{\circ} \mathrm{C}$ (Wijffels et al. 2008).

Direct current measurements were carried out at different channels at times before the INSTANT field program, when an array of 11 moorings were deployed in the two major inflow passages of Makassar and Lifamatola Straits, and the three major outflow passages of Lombok, Ombai and Timor over a 3-year period during 20042006 (Sprintall et al. 2009). The best estimate of the total transport from the three exit passages into the Indian Ocean is about $15 \mathrm{~Sv}$ (Fig. 1), which was slightly higher than that estimated from the sum of previous direct measurements at different times. During the INSTANT period, the total transport measured through the main entrance channel, the Makassar Strait, was 11.6Sv (Gordon et al. 2008).

The ITF experienced substantial interannual and decadal variations, influenced by the Indian and Pacific wind forcing. Direct observations from the IX1 XBT data showed that there is a clear relationship between the ITF transport and the El Niño-Southern Oscillation (ENSO)-the ITF is stronger during La Niña and weaker during El Niño, with a pick-to-trough amplitude of $5 \mathrm{~Sv}$ (Meyers 1996). Wijffels and Meyers (2004) found that about $60-90 \%$ of sea level variability and $70 \%$ of thermocline temperature variability within the Indonesian seas and southeast Indian Ocean can be understood in terms of free Kelvin and Rossby waves generated by remote zonal winds along the equator of the Indian and Pacific Oceans, which is consistent with the theory that the intersection of the two ocean waveguides drives the variability of the ITF (Clarke and Liu 1994). The transmitted signals from the two equatorial waveguides also affect the upper ocean thermal structures associated with the ITF (Wijffels and Meyers 2004). Thus, the transmitted ENSO signals, high sea levels during La Niña and low sea levels during El Niño, are associated with the upper ocean thermal structure variations that drive the ENSO variability of the ITF geostrophic transport.

From data-assimilating model results, it is noted that the ITF transport variability actually lagged the ENSO variability by 9 months (England and Huang 2005). Based on the IX1 XBT data, Liu et al. (2015) found that the often co-occurring Indian Ocean Dipole (negative Indian Ocean Dipole) with El Niño (La Niña) actually counter the direct ENSO effect during the developing phase of ENSO, resulting the delayed ITF transport response to ENSO variability (Fig. 2). It was suggested that the Indian Ocean Dipole may have strong impact on the ITF transport through the Lombok and Ombai Straits (Potemra and Schneider 2007; Sprintall and Révelard 2014).

Decadal variations of the tropical Pacific and Indian Ocean winds also drive decadal variations of the ITF

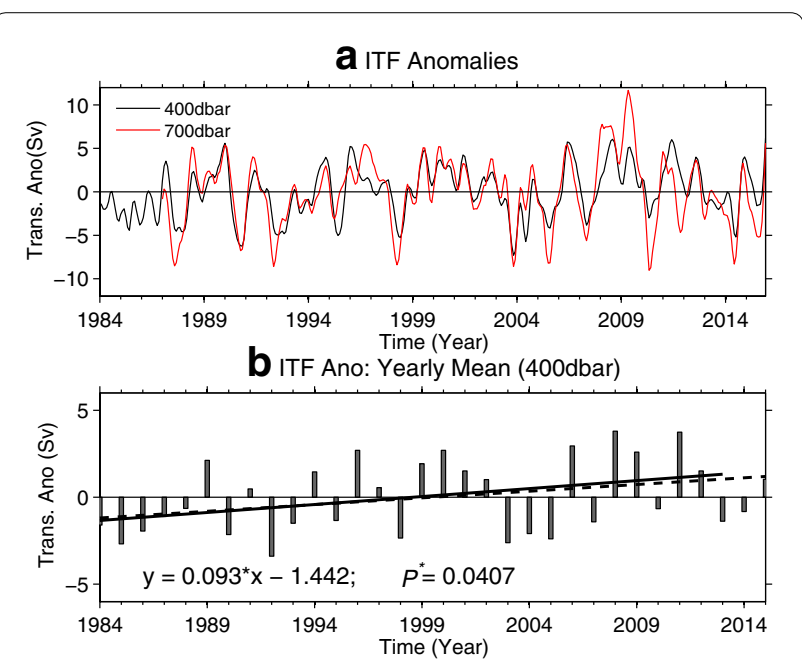

Fig. 2 The ITF transport anomalies estimated by IX1 XBT data. a Monthly time series of the ITF transport anomalies estimated by IX1 XBT temperatue records and monthly $T-S$ relationship, with reference depths of 400 and 700 m, respectively, from January 1984 to December 2015. b Annual mean ITF transport anomalies with a reference depth of $400 \mathrm{dbar}$, and their linear trends during 1984-2013 (Liu et al. 2015), and during 1984-2015. The linear regression coefficients and 95\% significance test are for the 1984-2013 period

transport. Whereas there was lack of decadal model of climate variability in the Indian Ocean (Han et al. 2014), decadal variations of the ITF transport are mainly associated with the decadal climate mode in the Pacific, such as the Pacific Decadal Oscillation or the Interdecadal Pacific Oscillation (Zhuang et al. 2013). The IPO entered into a positive phase after the mid-1970s climate regime shift, and reverted back to a negative phase after the 1997-98 El Niño. Positive phase of the IPO is associated with weaker than normal trade winds, whereas negative phase of the IPO is associated with stronger than normal trade winds.

By comparing the IX1 XBT temperature records with historical observations back in the 1950s-1960s, there were subsurface cooling anomalies in the southern portion of the section after mid-1970s, which corresponding to a weakened ITF geostrophic transport compared with the early decades (Wainwright et al. 2008). The weakening trend of the ITF from 1960s to 1990s was attributed to weakened Pacific trade winds after the mid-1970 climate regime shift (Wainwright et al. 2008; Liu et al. 2010). Since the mid-1990s, the ITF transport appeared to have rebounded in response to the strengthened Pacific Walker Circulation in the negative phase of the Interdecadal Pacific Oscillation (Fig. 2; Feng et al. 2011; Liu et al. 2015). The strengthening trend of the ITF geostrophic transport across the IX1 XBT section is about 1Sv every 10 year during 1984-2013 (Liu et al. 2015), though the trend may have reversed due to the influence 
of the recent El Nino events in 2014-2016 (Fig. 2). From model simulations, it was suggested that the more frequent La Nina events during the negative phase of the IPO tended to drive higher than normal ITF transport, resulting in a redistribution of anthropogenic heat uptake from the Pacific to the Indian Ocean (Lee et al. 2015).

\section{Proxies of the ITF transport variability}

Direct measuring the ITF transport has been challenging, and there have been many studies using various proxies to estimate the ITF transport. Some directly use the surface pressure gradient between the Pacific and Indian Ocean, while others use processes that influence the pressure difference between the two ocean, such as buoyancy forcing and wind forcing. In this study, we summarise different proxy methods for the ITF transport estimation.

\section{Sea levels and pressures}

Wyrtki (1987) hypothesized that a pressure gradient between the Pacific and Indian Oceans drives a flow of Pacific water through the Indonesian archipelago into the Indian Ocean. Sea levels in the western Pacific and eastern Indian Ocean have since been used as proxies for the ITF transport. The sea levels in the tropical Pacific drive the variability in the along the Australian coast and in the southeast Indian Ocean, whereas the sea levels in the tropical Indian Ocean drive the variability along the Indonesian coast, through oceanic equatorial and coastal waveguides (Clarke and Liu 1994). Potemra et al. (1997) expanded Wyrtki's original concept by including sea level derived by satellite altimetry at additional locations and by using satellite altimetry to determine that sea level. The concept was further expanded (Potemra 2005) by using both concurrent and leading or lagging sea level data. He noted that sea-level locations of Clarke and Liu (1994), and those proposed by Wyrtki (1987) do, in fact, produce a good estimate of upper-ocean ITF transport, but more complex, wider-area forcing is required for total depth ITF transport. Satellite altimetry data has been used to construct an ITF transport proxy from 1993 to present.

By using SODA assimilation, Du and Qu (2010) suggested the difference in vertically integrated dynamic height between north of New Guinea and south of Java as a good proxy of the ITF transport on the interannual scale, which implied a significant origin of the ITF interannual variability in the South Pacific. It has been found from a data-assimilating model that the decadal variations of the ITF is mostly related to the sea level variability remotely forced from the Pacific, so that the sea level records at Fremantle of Western Australia can be used as a proxy for the ITF transport associated with the decadal climate variability in the Pacific (Zhuang et al. 2013). By comparing the observation in Makassar Strait and model outputs, Tillinger and Gordon (2009) concluded that the ocean states take an important effect to influence the ITF transport, and the pressure difference displays a better skill in replicating the observations, not only with ENSO but also at decadal scale.

Susanto and Song (2015) used altimeter sea surface height (the sea level difference between any point in the western Pacific and in the eastern Indian Ocean) and gravity ocean bottom pressure data, to derive an ITF proxy. It is an expansion of (Wyrtki 1987; Potemra et al. 1997, 2005). They determined the optimal correlation between the Makassar Strait transport and the pressure gradients across the two oceans, concurrent with the wave dynamics coming from the central Pacific and Indian Oceans, respectively.

\section{Buoyancy forcing, downstream buoyant pools}

Salinity plays a role to regulate the ITF transport. The advection of freshwater from the Indonesian seas results in an average freshening of $0.2 \mathrm{psu}$ in Indonesian Australian basin during strong La Nina events (Phillips et al. 2005; Zhang et al. 2016). The T-S relationship with better resolution of the low-salinity signature can result in a stronger seasonal cycle of the ITF geostrophic transport (Liu et al. 2005). Andersson and Stigebrandt (2005) proposed that the buoyancy forcing associated with freshwater gain and vertical mixing in the northern and equatorial Pacific is an important factor to determine the pressure gradient between the ocean basins and force the ITF transport from the Pacific to the Indian Ocean. They used the downstream buoyant pool calculation to derive a proxy for the ITF transport.

For the interannual variability of the ITF transport, $\mathrm{Hu}$ and Sprintall (2016) noted that there are about 36\% contributions from the salinity. The proxy of the ITF transport, built by the density gradient of Indo-Pacific ( $\mathrm{Hu}$ and Sprintall 2017), shows reasonable agreement with observed interannual variability and decadal trend of the ITF (Liu et al. 2015). Gordon et al. (2012) suggested that the variability of Makassar Strait Throughflow is caused by the alternate building/dissipating of a freshwater plug in the western Sulawesi Sea and Java Sea that are related to ENSO-dominated variability in the South China Sea Throughflow.

\section{Godfrey's Island Rule}

Using Sverdrup Balance and the Island Rule, the ITF transport can also be determined by integrating wind stresses in the south Pacific and around Australia (Godfrey 1989, 1996),

$$
T_{\mathrm{ITF}}=\frac{1}{f_{N}-f_{\mathrm{S}}} \oint \frac{\tau^{l}}{\rho_{0}} \mathrm{~d} l
$$


$\tau^{l}$ is the along route wind stress and the integration route of wind stress is shown in Fig. 3. $f_{\mathrm{S}}$ is the Coriolis parameter at the southern leg of the integration route, $44^{\circ} \mathrm{S}$, and $f_{N}$ is the Coriolis parameter at the equator, zero.

That is, Godfrey's Island Rule estimates the depth-integrated throughflow by the Sverdrup transport integrated across the Pacific and meridionally averaged over the latitudes of Australia-Papua New Guinea (PNG) plus a component due to integrating the alongshore wind stress around Australia-PNG. Wajsowicz (1993) extended the Island Rule for application to the ITF by including bottom topography and noted the narrow, shallow channels of the Indonesian seas which allow both ocean basins to exert control over the flow via frictional and nonlinear effects. The Leeuwin Current off the west coast of
Australia would also have a non-negligible contribution to the friction at the eastern boundary (Feng et al. 2005).

Godfrey's Island Rule yields an estimate of the transport which is surprisingly robust and generally agreeable with values from numerical experiments (e.g. Schiller et al. 1998). Godfrey's Island Rule has also been used to explain the southward intensification of the Southern Ocean super-gyre circulation on multi-decadal time scale, including a strengthening of the East Australian Current flow through the Tasman Sea, due to a strengthening of the circumpolar westerly and a weakening of the mid-latitude westerly (Cai 2006). The Island Rule is able to capture some of the decadal/multi-decadal variations of the ITF (Wainwright et al. 2008; Feng et al. 2011; Zhuang et al. 2013). The South China Sea throughflow
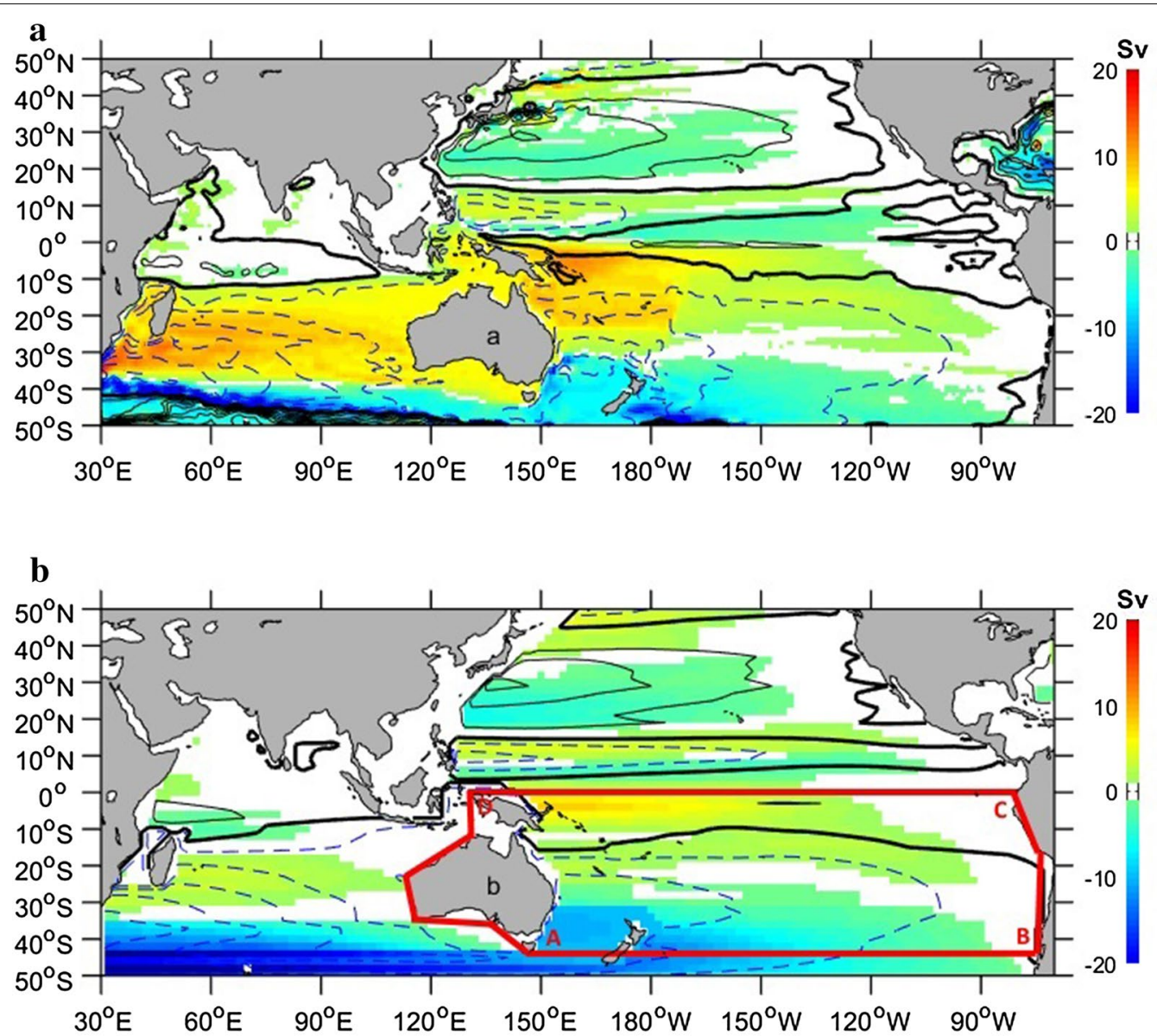

Fig. 3 Mean and linear changes of barotropic stream function from model and the Island Rule. a Mean (contour) and linear changes (shading) of barotropic stream functions in the Indo-Pacific Ocean during 2006-2101 from the OFAM3 RCP8.5 run; b mean (contour) and linear changes (shading) in stream functions during 2006-2101 derived from the Sverdrup Balance and Island Rule; The mean stream functions in (a) and (b) are from the OFAM3 historical run during 1979-2014 and their linear changes are derived from the RCP8.5 run. The contour interval for the mean stream functions is $10 \mathrm{~Sv}$, with heavy black contours denoting the zero stream functions and blue dashed contours denoting negative values. Linear changes of less than 1Sv are not shown. In (b), the red lines delineate the integration route for the wind stress in the Island Rule calculation. (Reproduced with permission from (Feng et al. 2017)) 
and variability have also been explained by the Island Rule (Qu et al. 2005; Wang et al. 2006). Mostly, the variability of the ITF transport is out-of-phase with the South China Sea Throughflow (Liu et al. 2006), which can be well explained by the Island Rule theory.

\section{Centennial change of the ITF}

Whereas wind-driven circulation theory (Island Rule) is able to explain the decadal variations of the ITF volume transport, there have been model projections of a declining trend of the ITF which cannot be explained by the wind-driven circulation (Sen Gupta et al. 2016; Feng et al. 2017). Other proxies of the ITF may not valid either on the centennial time scale.

Climate models consistently project a substantial decrease in the ITF transport in response to enhanced greenhouse warming, with a multi-model mean reduction of $3.4 \mathrm{~Sv}$ by the end of the century, corresponding to over $20 \%$ of the multi-model mean ITF transport of $15 \mathrm{~Sv}$ (Sen Gupta et al. 2016). It is suggested that the declining trend of the ITF in the future climate cannot be determined by the Island Rule, but is associated with a weakening trend of deep water formation in the Southern Ocean and a slowdown of upwelling in the deep Pacific Ocean (sen Gupta et al. 2016). Downscaling the future climate change on ocean circulation using an eddy-rich $(10 \mathrm{~km})$ near-global ocean model also captures similar declining trend of the ITF and the slowdown of the deep upwelling in the Pacific basin (Feng et al. 2017).

Feng et al. (2017) formalised the relationship of the ITF volume transport with the wind-driven circulation and deep Pacific upwelling, by amending the Island Rule, that is,

$$
T_{\mathrm{ITF}}=\frac{1}{f_{N}-f_{\mathrm{S}}} \oint_{\mathrm{ABCD}} \frac{\tau^{l}}{\rho_{0}} \mathrm{~d} l+\iint_{\text {Pacific }} w_{Z} \mathrm{~d} s .
$$

The first term on the right hand side is the traditional Island Rule wind stress integration and the second term is the additional contribution from deep upwelling across the Pacific basin. The amended Island Rule is able to capture the interannual to decadal, as well as centential changes of the ITF as in an eddy-rich ocean model simulation (Feng et al. 2017). The amended Island Rule and the model simulation confirmed that the weakening of the ITF transport in the future climate is mostly attributed to the slowdown of the deep upwelling in the Pacific, which implies that the deep contribution to the ITF will be weakening in the future warm climate, influenced by stronger near water column stratification and reduction of deep water formation rate. The connection between the changes of global overturning circulation and the
ITF on centennial timescale need further research (Sen Gupta et al. 2016; Feng et al. 2017).

\section{Implications for the Indo-Pacific Ocean}

The OFAM3 simulation of Feng et al. (2017) captures the spatial structure of the thermocline depth in the Indo-Pacific Ocean, the subtropical gyres and associated boundary current systems, as represented by the $14{ }^{\circ} \mathrm{C}$ isothermal depth (Fig. 4). Over 80 years under the RCP8.5 climate forcing, the ocean warming drives the isotherm to deepen by $40.8 \mathrm{~m}$ on average in the IndoPacific Ocean. The long term changes of the $14{ }^{\circ} \mathrm{C}$ isothermal depth have some distinct spatial patterns. The negative relative changes across the subtropical southern Indian Ocean emanated from the Australian coast are associated with the weakening of the ITF. These signals appear to be connected to negative relative changes in the subtropical northern Pacific, channelled through the Indonesian Seas. In the close-open ITF model experiment, the exchange between the two hemispheres are significantly reduced when the ITF channels are closed (Lee et al. 2002).

There have been observations of persistent subsurface cooling in the subtropical southern Indian Ocean, which have been attributed to both local Indian Ocean wind forcing and remote Pacific influences (Han et al. 2014). The weakening ITF due to climate change may also contribute to the persistent subsurface cooling in the Indian Ocean. The changes of the thermal structure of the southern Indian Ocean associated with the ITF will likely weaken the South Indian Ocean Counter Current and the Leeuwin Current systems, which may need further assessment with the downscale models. The full impacts of the weakening ITF on the climate system of the IndoPacific Ocean can only be assessed with coupled oceanatmosphere models.

\section{Summary}

In this study, we have reviewed research progresses of observations of the ITF and its variability, as well as various ITF proxies on its interannual-decadal variations including Godfrey's Island Rule. Through model assessment, we have reviewed the centennial changes of the ITF transport associated with thermohaline circulation and the implication for the Indo-Pacific Ocean circulation. The key messages are as follows:

- The ITF has an average volume transport of about $15 \mathrm{~Sv}$, with surface waters mainly sourced from the North Pacific, through the Mindanao Current and the Makassar Strait; whereas the South Pacific waters can also reach to the Mindanao Current through nonlinear processes and the deeper ITF is dominated 

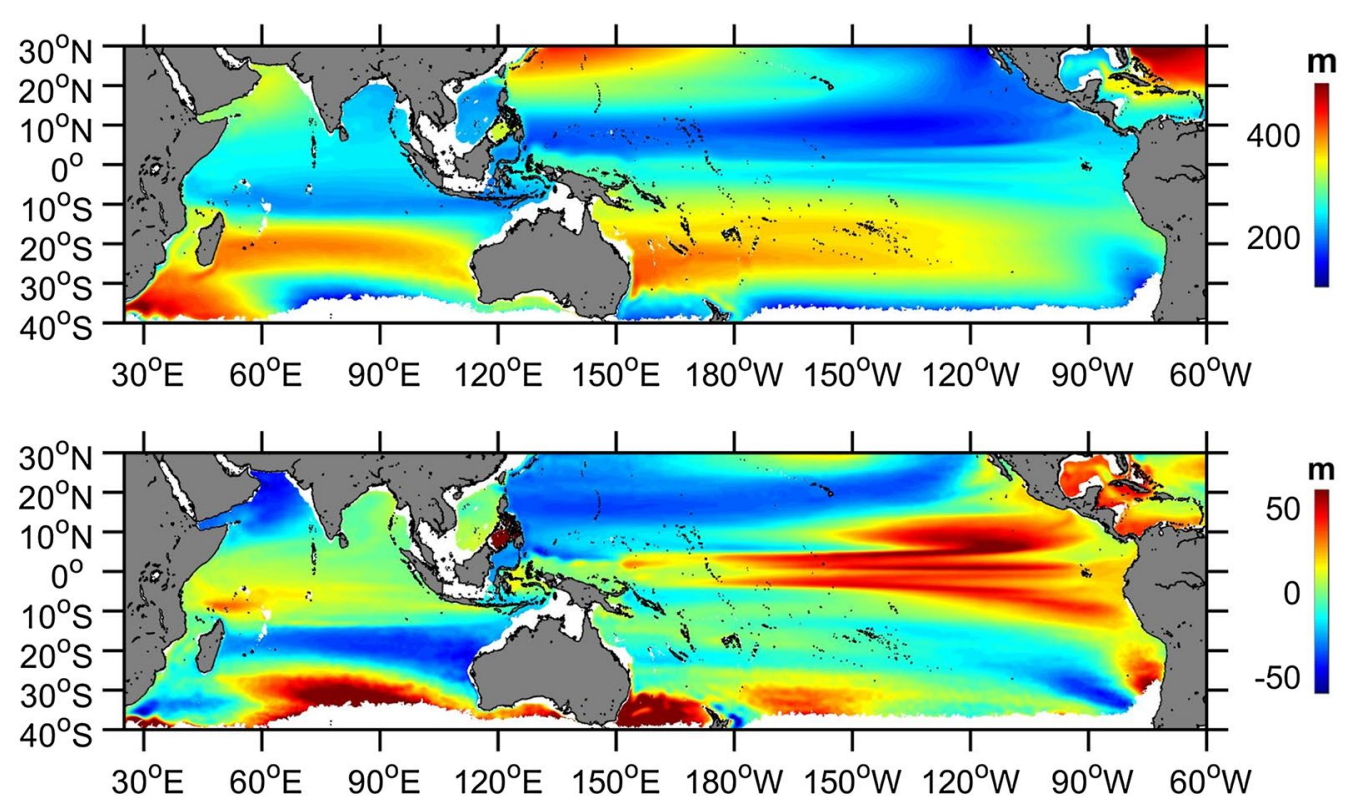

Fig. $414^{\circ} \mathrm{C}$ isotherm depth over the Indo-Pacific Ocean. (top panel) Average $14^{\circ} \mathrm{C}$ isotherm depth over the Indo-Pacific Ocean during 2006-2026, and (lower panel) average $14^{\circ} \mathrm{C}$ isotherm depth difference between 2081 and 2101 and 2006-2026 in an OFAM3 simulation forced by RCP8.5 climate change forcing. A mean difference of $40.8 \mathrm{~m}$ has been removed from the lower panel

by saline South Pacific lower-thermocline water penetrating into the Seram Sea.

- Under the wind forcing from the Indian and Pacific Oceans, the ITF has significant interannual variabilities, with ENSO and IOD events, of about 5Sv. Most of the interannual variability of the ITF can be understood in terms of free Kelvin and Rossby waves (intersection of the two ocean waveguides) generated by remote zonal winds along the equator of the Indian and Pacific Oceans. Decadal variability of the ITF can be mainly attributed to the Pacific wind forcing.

- Interannual and decadal variations of the ITF can be derived from proxies such as sea level/pressure differences between the Pacific and Indian Ocean, and wind stresses based on Godfrey's Island Rule, which is the major reason why the variability of ITF acts out-of-phase with South China Sea throughflow.

- On Centennial time scales, the weakening trend of the ITF in the future climate cannot be determined by the Island Rule and other proxy estimations. The weakening of deep water formation in the Southern Ocean and a slowdown of upwelling in the deep Pacific Ocean play a more dominant role in determining the declining trend of the ITF. It is thus crucial to have a better understanding of the interaction between the wind-driven and thermohaline circula- tion in relation to the ITF variability, and how the future trend of the ITF affect basin scale thermohaline structure and circulation in the Indo-Pacific Ocean.

\section{Abbreviations}

ENSO: El Nino Southern Oscillation; ITF: Indonesian throughflow; INSTANT: International Nusantara Stratification and Transport Program; IOD: Indian Ocean dipole; IPO: Interdecadal Pacific Oscillation; RCP: Representative Concentration Pathways; SCS: South China Sea; SCSTF: South China Sea throughflow; SODA: simple ocean data assimilation; SST: sea surface temperature; XBT: expendable bathythermograph.

\section{Authors' contributions}

MF wrote the major parts of the manuscript. NZ and QL supplemented some parts of the manuscript. All authors read and approved the final manuscript.

\section{Author details}

${ }^{1}$ CSIRO Oceans and Atmosphere, Indian Ocean Marine Research Centre, Crawley, WA, Australia. ${ }^{2}$ Centre for Southern Hemisphere Oceans Research, CSIRO Oceans and Atmosphere, Hobart, TAS, Australia. ${ }^{3}$ School of Marine Sciences, Nanjing University of Information Science and Technology, Nanjing, China. ${ }^{4}$ South China Sea Institute of Oceanology, Chinese Academy of Sciences, Guangzhou, China.

\section{Acknowledgements}

This work is dedicated to the memory of the vision and commitment of Gary Meyers in using observations to drive insight into earth's climate variability. MF would like to thank Robin Robertson and Charles Lemchert for encouragement to deliver the Distinguished Lecture at the AOGS conference. MF would also like to thank Dwi Susanto, Dongxiao Wang, and Dongliang Yuan for constructive discussions on the ITF research.

\section{Competing interests}

The authors declare that they have no competing interests. 


\section{Availability of data and materials}

Not applicable.

\section{Ethical approval and consent to participate}

Not applicable.

\section{Funding}

This work is supported by the Centre for Southern Hemisphere Oceans Research (CSHOR) and CAS/SAFEA International Partnership Program for Creative Research Teams, and the Integrated Marine Observing System (IMOS) program. CSHOR is a joint initiative between the Qingdao National Laboratory for Marine Science and Technology (QNLM), CSIRO, University of New South Wales and University of Tasmania. QL was supported by the National Basic Research Program of China Project 41628601.

\section{Publisher's Note}

Springer Nature remains neutral with regard to jurisdictional claims in published maps and institutional affiliations.

Received: 25 October 2017 Accepted: 10 January 2018

Published online: 29 January 2018

\section{References}

Andersson HC, Stigebrandt A (2005) Regulation of the Indonesian throughflow by baroclinic draining of the North Australian Basin. Deep Res Part I 52:2214-2233. https://doi.org/10.1016/j.dsr.2005.06.014

Cai W (2006) Antarctic ozone depletion causes an intensification of the Southern Ocean super-gyre circulation. Geophys Res Lett. https://doi. org/10.1029/2005GL024911

Clarke AJ, Liu X (1994) Interannual sea level in the northern and eastern Indian Ocean. J Phys Oceanogr 24:1224-1235. https://doi. org/10.1175/1520-0485(1994)024<1224:ISLITN>2.0.CO;2

Domingues CM, Maltrud ME, Wijffels SE et al (2007) Simulated Lagrangian pathways between the Leeuwin Current system and the upper-ocean circulation of the southeast Indian Ocean. Deep Res Part II 54:797-817. https://doi.org/10.1016/j.dsr2.2006.10.003

Du Y, Qu T (2010) Three inflow pathways of the Indonesian throughflow as seen from the simple ocean data assimilation. Dyn Atmos Oceans 50:233-256. https://doi.org/10.1016/j.dynatmoce.2010.04.001

Durgadoo JV, Rühs S, Biastoch A, Böning CW (2017) Indian Ocean sources of Agulhas leakage. J Geophys Res Oceans 122(4):3481-3499

England $\mathrm{MH}$, Huang $\mathrm{F}$ (2005) On the interannual variability of the Indonesian throughflow and its linkage with ENSO. J Clim 18:1435-1444. https://doi. org/10.1175/JCLI3322.1

Fang G, Susanto RD, Wirasantosa S, Qiao F, Supangat A, Fan B, Wei Z, Sulistiyo B, Li S, (2010) Volume, heat, and freshwater transports from the South China Sea to Indonesian seas in the boreal winter of 2007-2008. J Geophys Res Oceans 115(C12):C12020

Feng M, Wijffels S, Godfrey S, Meyers G (2005) Do eddies play a role in the momentum balance of the Leeuwin Current? J Phys Oceanogr 35:964975. https://doi.org/10.1175/JPO2730.1

Feng M, Böning C, Biastoch A et al (2011) The reversal of the multi-decadal trends of the equatorial Pacific easterly winds, and the Indonesian throughflow and Leeuwin Current transports. Geophys Res Lett 38:L11604. https://doi.org/10.1029/2011GL047291

Feng M, Zhang X, Sloyan B, Chamberlain M (2017) Contribution of the deep ocean to the centennial changes of the Indonesian throughflow. Geophys Res Lett 44:2859-2867. https://doi.org/10.1002/2017GL072577

Ffield A, Gordon AL (1996) Tidal mixing signatures in the Indonesian seas. J Phys Oceanogr 26:1924-1937

Fieux M, AndriÉ C, Delecluse P et al (1994) Measurements within the PacificIndian oceans throughflow region. Deep Res Part I 41:1091-1130. https:// doi.org/10.1016/0967-0637(94)90020-5

Fieux M, Molcard R, llahude AG (1996) Geostrophic transport of the PacificIndian oceans throughflow. J Geophys Res 101:12421-12432. https://doi. org/10.1029/95JC03566

Fine RA (1985) Direct evidence using tritium data for throughflow from the Pacific into the Indian Ocean. Nature 315:478-480. https://doi. org/10.1038/315478a0
Gentilli J (1972) Thermal anomalies in the eastern Indian Ocean. Nature 238:93-95. https://doi.org/10.1038/physci238093a0

Godfrey JS (1989) A sverdrup model of the depth-integrated flow for the world ocean allowing for island circulations. Geophys Astrophys Fluid Dyn 45:89-112. https://doi.org/10.1080/03091928908208894

Godfrey JS (1996) The effect of the Indonesian throughflow on ocean circulation and heat exchange with the atmosphere: a review. J Geophys Res 101:12217-12237. https://doi.org/10.1029/95JC03860

Godfrey JS, Golding TJ (1981) The Sverdrup relation in the Indian Ocean, and the effect of Pacific-Indian Ocean throughflow on the Indian Ocean circulation and on the East Australian Current. J Phys Ocean 11:771-779. https://doi.org/10.1175/1520-0485(1981)011<0771:TSRITI>2.0.CO;2

Godfrey JS, Hirst AC, Wilkin J (1993) Why does the Indonesian throughflow appear to originate from the North Pacific? J Phys Oceanogr 23:10871098. https://doi.org/10.1175/1520-0485(1993)023<1087:WDTITA>2.0. $\mathrm{CO} ; 2$

Gordon AL (1986) Interocean exchange of thermocline water. J Geophys Res 91:5037-5046. https://doi.org/10.1029/JC091iC04p05037

Gordon AL (2005) Oceanography of the Indonesian Seas and their throughflow. Oceanography 18:14-27. https://doi.org/10.5670/oceanog.2005.01

Gordon AL, Fine RA (1996) Pathways of water between the Pacific and Indian oceans in the Indonesian seas. Nature 379:146-149. https://doi. org/10.1038/379146a0

Gordon AL, Susanto RD, Ffield A et al (2008) Makassar Strait throughflow, 2004 to 2006. Geophys Res Lett 35:L24605. https://doi. org/10.1029/2008GL036372

Gordon AL, Sprintall J, Van Aken HM et al (2010) The Indonesian throughflow during 2004-2006 as observed by the INSTANT program. Dyn Atmos Ocean 50:115-128. https://doi.org/10.1016/j.dynatmoce.2009.12.002

Gordon AL, Huber BA, Metzger EJ et al (2012) South China Sea throughflow impact on the Indonesian throughflow. Geophys Res Lett 39:L11602. https://doi.org/10.1029/2012GL052021

Han W, Vialard J, McPhaden MJ et al (2014) Indian ocean decadal variability: a review. Bull Am Meteorol Soc 95:1679-1703. https://doi.org/10.1175/ BAMS-D-13-00028.1

Hirst AC, Godfrey JS (1993) The role of Indonesian throughflow in a Global Ocean GCM. J Phys Oceanogr 23:1057-1086. https://doi. org/10.1175/1520-0485(1993)023<1057:TROITI>2.0.CO;2

Hu S, Sprintall J (2016) Interannual variability of the Indonesian throughflow: the salinity effect. J Geophys Res Oceans 121:2596-2615. https://doi. org/10.1002/2015JC011495

Hu S, Sprintall J (2017) Observed strengthening of interbasin exchange via the Indonesian seas due to rainfall intensification. Geophys Res Lett 44:1448-1456. https://doi.org/10.1002/2016GL072494

Koch-Larrouy A, Atmadipoera A, Van Beek P, Madec G, Aucan J, Lyard F, Grelet J, Souhaut M (2015) Estimates of tidal mixing in the Indonesian archipelago from multidisciplinary INDOMIX in situ data. Deep Sea Res Part I 106:136-153

Lee T, Fukumori I, Menemenlis D et al (2002) Effects of the Indonesian throughflow on the Pacific and Indian oceans. J Phys Oceanogr 32:1404-1429. https://doi.org/10.1175/1520-0485(2002)032<1404:Eotito>2.0.Co:2

Lee S-K, Park W, Baringer MO et al (2015) Pacific origin of the abrupt increase in Indian Ocean heat content during the warming hiatus. Nat Geosci 8:445-450. https://doi.org/10.1038/ngeo2438

Liu Y, Feng M, Church J, Wang D (2005) Effects of salinity on estimating geostrophic transport of the Indonesian throughflow along the IX1 XBT section. J Oceanogr 61:795-801

Liu Q, Huang RX, Wang D, Xie Q, Huang Q (2006) Interplay between the Indonesian throughflow and the South China Sea throughflow. Chin Sci Bull 51((II)):50-58

Liu Q, Wang D, Zhou W et al (2010) Covariation of the Indonesian throughflow and South China Sea throughflow associated with the 1976/77 regime shift. Adv Atmos Sci 27:87-94. https://doi.org/10.1007/ s00376-009-8061-3

Liu Q, Feng M, Wang D, Wijffels S (2015) Interannual variability of the Indonesian throughflow transport: a revisit based on 30 year expendable bathythermograph data. J Geophys Res Oceans 120:8270-8282. https:// doi.org/10.1002/2015JC011351

Macdonald A (1993) Property fluxes at $30^{\circ} \mathrm{S}$ and their implications for the Pacific-Indian throughflow and the global heat budget. J Geophys Res 98:6851-6868. https://doi.org/10.1029/92JC02964 
Menezes W, Phillips HE, Schiller A, Domingues C, Bindoff NL (2013) Salinity dominance on the Indian Ocean Eastern Gyral Current. Geophys Res Lett 40:1-6. https://doi.org/10.1002/2013GL057887

Meyers G (1996) Variation of Indonesian throughflow and the El NiñoSouthern Oscillation. J Geophys Res 101:12255-12263. https://doi. org/10.1029/95JC03729

Meyers G, Bailey RJ, Worby AP (1995) Geostrophic transport of Indonesian throughflow. Deep Res Part I 42:1163-1174. https://doi. org/10.1016/0967-0637(95)00037-7

Murtugudde R, Busalacchi AJ, Beauchamp J (1998) Seasonal-to-interannual effects of the Indonesian throughflow on the tropical Indo-Pacific Basin. J Geophys Res 102:21425-21441. https://doi.org/10.1029/98JC02063

Nicholls N (1984) The Southern Oscillation and Indonesian sea surface temperature. Mon Weather Rev 112:424-432. https://doi. org/10.1175/1520-0493(1984)112<0424:TSOAIS>2.0.CO;2

Nof D (1996) What controls the origin of the Indonesian throughflow? J Geophys Res 101:12301-12314. https://doi.org/10.1029/95JC03440

Phillips HE, Wijffels SE, Feng M (2005) Interannual variability in the freshwater content of the Indonesian-Australian Basin. Geophys Res Lett 32:L03603. https://doi.org/10.1029/2004GL021755

Potemra JT (2005) Indonesian throughflow transport variability estimated from satellite altimetry. Oceanography 18:98-107. https://doi.org/10.5670/ oceanog.2005.10

Potemra JT, Schneider N (2007) Interannual variations of the Indonesian throughflow. J Geophys Res Ocean 112:C05035. https://doi. org/10.1029/2006JC003808

Potemra JT, Lukas R, Mitchum GT (1997) Large-scale estimation of transport from the Pacific to the Indian Ocean. J Geophys Res 102:27795-27812. https://doi.org/10.1029/97JC01719

Qu T, Meyers G, Godfrey JS, Hu D (1994) Ocean dynamics in the region between Australia and Indonesia and its influence on the variation of sea surface temperature in a global general circulation model. J Geophys Res 99:18433-18445. https://doi.org/10.1029/94JC00858

Qu T, Du Y, Meyers G, Ishida A, Wang D (2005) Connecting the tropical Pacific with Indian Ocean through South China Sea. Geophys Res Lett 32:L24609. https://doi.org/10.1029/2005GL024698

Qu T, Du Y, Sasaki H, (2006) South China Sea throughflow: a heat and freshwater conveyor. Geophys Res Lett 33(23)

Schiller A, Godfrey JS, Mclntosh PC, Meyers G, Wijffels SE (1998) Seasonal near-surface dynamics and thermodynamics of the Indian Ocean and Indonesian throughflow in a global ocean general circulation model. J Phys Oceanogr 28(11):2288-2312

Sen Gupta A, McGregor S, Sebille E, Ganachaud A, Brown J, Santoso A (2016) Future changes to the Indonesian throughflow and Pacific circulation: the differing role of wind and deep circulation changes. Gephys Res Lett 43:1669-1678

Sloyan BM, Rintoul SR (2001) Circulation, renewal, and modification of Antarctic mode and intermediate water. J Phys Oceanogr 31:1005-1030. https:// doi.org/10.1175/1520-0485(2001)031<1005:CRAMOA>2.0.CO;2

Sprintall J, Révelard A (2014) The Indonesian throughflow response to IndoPacific climate variability. J Geophs Res Ocean 119:1161-1175. https://doi. org/10.1002/2013JC009533

Sprintall J, Wijffels S, Gordon AL et al (2004) INSTANT: a new international array to measure the Indonesian throughflow. Eos Trans Am Geophys Union 85:369-376. https://doi.org/10.1029/2004EO390001

Sprintall J, Wijffels SE, Molcard R, Jaya I (2009) Direct estimates of the Indonesian throughflow entering the Indian Ocean: 2004-2006. J Geophys Res 114:C07001. https://doi.org/10.1029/2008JC005257
Sprintall J, Gordon AL, Koch-Larrouy A et al (2014) The Indonesian seas and their role in the coupled ocean-climate system. Nat Geosci 7:487-492. https://doi.org/10.1038/ngeo2188

Susanto RD, Song YT (2015) Indonesian throughflow proxy from satellite altimeters and gravimeters. J Geophys Res Ocean 120:2844-2855. https:// doi.org/10.1002/2014JC010382

Susanto RD, Wei Z, Adi RT, Fan B, Li S, Fang G (2013) Observations of the Karimata Strait througflow from December 2007 to November 2008. Acta Oceanol Sin 32(5):1-6

Tillinger D, Gordon AL (2009) Fifty years of the Indonesian throughflow. J Clim 22:6342-6355

Ummenhofer CC, Biastoch A, Böning CW (2017) Multidecadal Indian Ocean variability linked to the Pacific and implications for preconditioning Indian Ocean dipole events. J Clim 30(5):1739-1751

van Aken HM, Brodjonegoro IS, Jaya I (2009) The deep-water motion through the Lifamatola Passage and its contribution to the Indonesian throughflow. Deep Res Part I 56:1203-1216. https://doi.org/10.1016/j. dsr.2009.02.001

van Sebille E, Sprintall J, Schwarzkopf FU et al (2014) Pacific-to-Indian Ocean connectivity: Tasman leakage, Indonesian throughflow, and the role of ENSO. J Geophys Res Ocean 119:1365-1382. https://doi. org/10.1002/2013JC009525

Vranes K, Gordon AL, Ffield A (2002) The heat transport of the Indonesian throughflow and implications for the Indian Ocean heat budget. Deep Res Part II 49:1391-1410. https://doi.org/10.1016/S0967-0645(01)00150-3

Wainwright L, Meyers G, Wijffels S, Pigot L (2008) Change in the Indonesian throughflow with the climatic shift of 1976/77. Geophys Res Lett 35:L03604. https://doi.org/10.1029/2007GL031911

Wajsowicz RC (1993) The circulation of the depth-integrated flow around an island with application to the Indonesian throughflow. J Phys Oceanogr 23:1470-1484. https://doi.org/10.1175/1520-0485(1993)023<1470:TCOT $\mathrm{Dl}>2.0 . \mathrm{CO} ; 2$

Wang D, Liu Q, Huang RX, Du Y, Qu T (2006) Interannual variability of the South China Sea throughflow inferred from wind data and an ocean data assimilation product. Geophys Res Lett 33(14):L14605

Wijffels S, Meyers G (2004) An intersection of oceanic waveguides: variability in the Indonesian throughflow region. J Phys Oceanogr 34:1232-1253. https://doi.org/10.1175/1520-0485(2004)034<1232:AlOOWV>2.0.CO;2

Wijffels S, Meyers G, Godfrey JS (2008) A 20-yr average of the Indonesian throughflow: regional currents and the interbasin exchanges. J Phys Oceanogr 38:1965-1978

Wyrtki K (1961) Physical oceanography of the Southeast Asian waters. NAGA report, 2nd edn. Scripps Institution of Oceanography, San Diego. https:// doi.org/10.1017/S0025315400054370

Wyrtki K (1987) Indonesian through flow and the associated pressure gradient. J Geophys Res 92:12941-12946. https://doi.org/10.1029/ JC092iC12p12941

Zhang N, Feng M, Du Y, Lan J, Wijffels SE (2016) Seasonal and interannual variations of mixed layer salinity in the southeast tropical Indian Ocean. J Geophys Res Oceans 121(7):4716-4731

Zhuang W, Feng M, Du Y et al (2013) Low-frequency sea level variability in the southern Indian Ocean and its impacts on the oceanic meridional transports. J Geophys Res Ocean 118:1302-1315. https://doi.org/10.1002/ jgrc.20129 